\title{
Concentration of Nitrogen Oxides When Burning Wood Pellets of Various Origins
}

\author{
Bartosz Ciupek ${ }^{*}$, Karol Gołoś ${ }^{1}$ \\ 1 Institute of Thermal Energy, Faculty of Environmental and Power Engineering, Poznan University of \\ Technology, ul. Piotrowo 3, 60-965 Poznań, Poland \\ * Corresponding author's e-mail: bartosz.ciupek@put.poznan.pl
}

\begin{abstract}
The paper examined the impact of wood pellets of different type on the emission of nitrogen oxides $\left(\mathrm{NO}_{\mathrm{x}}\right)$ formed during the combustion process in a low-power heating boiler. The study aim was to determine the dependencies of the $\mathrm{NO}_{\mathrm{x}}$ emission levels on the chemical composition of fuel. The test was carried out using a model of a combustion chamber equipped with a dedicated burner. The analysis of the results confirmed the relationship between flue gas and the formation of $\mathrm{NO}_{\mathrm{x}}$. The obtained results prove the possibility of reorganizing the combustion process in order to reduce the $\mathrm{NO}_{\mathrm{x}}$ emission by selecting a proper composition of raw materials when producing wood pellets.
\end{abstract}

Keywords: nitrogen oxides, heating boiler, emission, wood pellet

\section{INTRODUCTION}

The environmental aspect of combustion processes has been long analysed by the scientists studying the ecological properties of combustion processes [Fiedler and Persson 2009; Hardy et al. 2012; Musialik-Piotrowska et al. 2010; Zhang and Smith 2007]. The basic principle of reviewing a heating boiler in relation to thermodynamics is to consider it as an open thermodynamic system with a strong impact on the environment, which results from the conversion of the chemical energy contained in the fuel into the thermal energy that is partially exchanged with the environment [Khodaei et al. 2015]. An inherent element of these processes, both in industrial and local power section, is the emission of harmful substances during combustion, which are closely related to the technical parameters of boilers [Boman et al. 2011; Hroncová et al. 2016; Morán et al. 2006; Müllerová et al. 2010; Rabczak and ProszakMiąsik 2016]. Another element that regulates the concentration of toxic compounds in flue gas is the type and chemical composition of fuel [Ciupek et al. 2019; Holubcik et al. 2018; Junga et al. 2017; Konieczyński et al. 2017].
The research conducted so far confirms that the combustion of fossil fuels and biomass of various sources has a direct impact on the environment [Ciupek 2019; El-Sayed and Khairy 2018; Filbakk et al. 2011; Joseph et al. 2018; Mitchell et al. 2016; Wiinikka and Gebart 2005]. Apart from introducing innovative methods of boiler construction and analyzing the diversity of the element contents in fuels, scientists have been conducting the research to increase the efficiency of the combustion process and minimize its negative environmental effects [Eskilsson et al. 2004; Kirsanovs et al. 2014; Polák and Neuberger 2008]. The main impact on the efficiency of the combustion process results from the method of supplying fuel to the furnace [Juszczak 2016]. On the other hand, limiting the emission of toxic compounds is associated with a proper organization of the combustion process, which directly affects the characteristics of the emitted harmful substances related to the air-fuel equivalence ratio $(\lambda)$ [Ciupek et al. 2019].

Due to a limited amount of naturally occurring fossil fuels and higher concentrations of toxic compounds released when burning, efforts are currently being made to increase the use of renewable 
fuels. An essential benefit of the biomass fuel combustion is that the process emits trace amounts of sulfur dioxide and significantly less particulate matter. The importance of using different types of pellets for energy purposes in Poland and around the world has been described in the cited publications [Cao and Pawłowski 2013; PiaskowskaSilarska 2014; Ratajczak et al. 2012].

The study was divided into three stages. The first stage involved determining the $\mathrm{NO}_{\mathrm{x}}$ emissions while burning the wood pellets made from deciduous tree waste - beech. The second part of the research examined the $\mathrm{NO}_{\mathrm{x}}$ emission levels during the pine pellet combustion, while the last stage involved burning the two previously mentioned fuels in the 50:50 ratio. The obtained test results were displayed in graphs as mass distributions of $\mathrm{NO}_{\mathrm{x}}$ and in tables containing the minimum, maximum and average measurements. Additionally, the relationship between the flue gas temperature changes and the $\mathrm{NO}_{\mathrm{x}}$ emissions for individual fuels was presented in the form of a chart.

\section{METHODS}

The test stand used in the study was a model of a cylindrical combustion chamber equipped with a burner assembly (a retort furnace and a blowing fan). The test system was connected to a water installation along with the required fittings.
Figure 1 presents the complete test setup diagram with a description.

Three types of fuel were supplied to the combustion process. The first fuel was the beech wood pellets, followed by the pine wood pellets, and the third fuel was a 50:50 mixture of the beech and pine pellets. The comparison of chemical compositions as well as the calorific values and the heat of fuel combustion are presented in Table 1.

The combustion chamber is equipped with an electronic controller that allows programming individual components. In consequence, before the measurement started, the combustion process had been stabilized in order to maximize efficiency and minimize the emission of pollutants. Fuels were periodically delivered by a drive unit with a screw feeder. Additionally, the system was equipped with an additional blowing fan speed controller that steadily supplied the air needed for the combustion process.

The measuring probe of the TESTO 330-2 LL flue gas analyzer was placed in the openings of the exhaust gas installation. The device was used to measure the composition of the flue gas and $\mathrm{NO}_{\mathrm{x}}$ concentration changes analyzed in the article. The PT100 sensor was used to measure the temperature of the flue gas. The obtained values of the $\mathrm{NO}_{\mathrm{x}}$ contents in the flue gas were subsequently calculated for $10 \%$ residual oxygen and converted to $\mathrm{mg} / \mathrm{m}^{3}$. The test method was based on the guidelines of the PN-EN 303-5: 2012 standard.

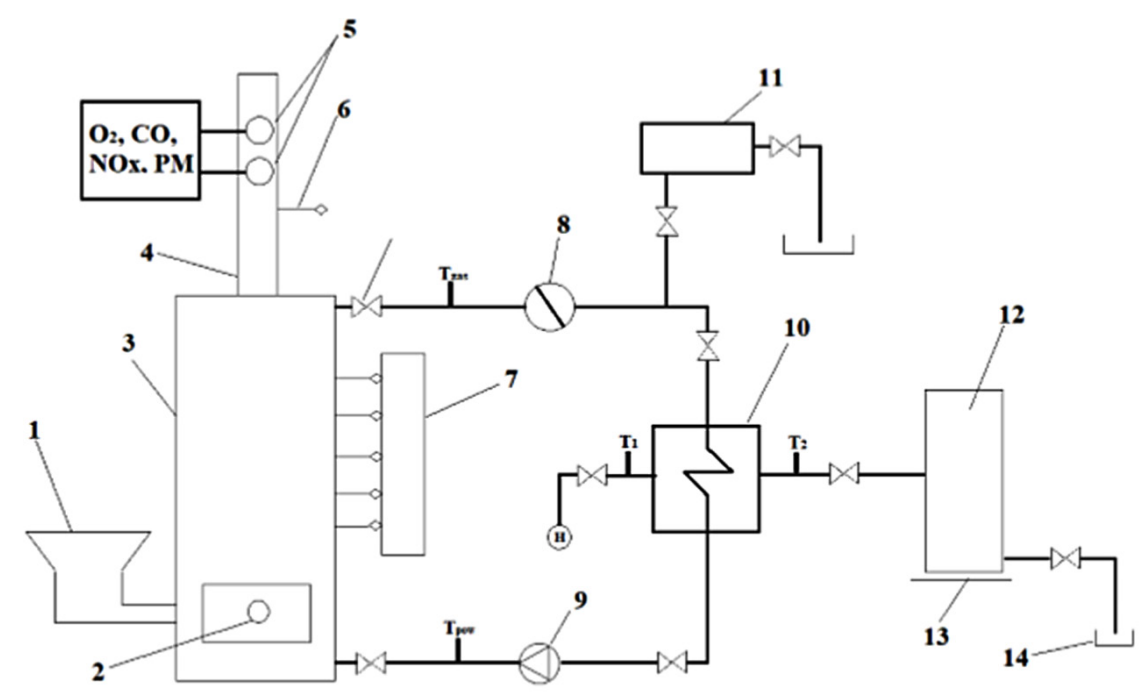

Specification: 1 - fuel tank with burner, 2 - viewing hole, 3 - combustion chamber, 4 - measuring exhaust outlet, 5 - set of exhaust gas analyzers, 6 - exhaust gas temperature measurement (thermocouples), 7 - thermocouple system for measuring temperatures inside the combustion chamber, 8 - flowmeter, 9 - circulation pump system, 10 - plate heat exchangers system, 11 - expansion vessel, 12 - water tank, 13 - weight, 14 - cooling water outflow

Fig. 1. Specification and diagram of the test setup 
Table 1. Technical parameters of fuels

\begin{tabular}{|c|c|c|c|c|c|c|c|c|}
\hline Fuel & $\begin{array}{c}\text { Carbon, } \\
\%\end{array}$ & $\begin{array}{c}\text { Hydrogen, } \\
\%\end{array}$ & $\begin{array}{c}\text { Oxygen, } \\
\%\end{array}$ & $\begin{array}{c}\text { Nitrogen, } \\
\%\end{array}$ & $\begin{array}{c}\text { Ash, } \\
\%\end{array}$ & $\begin{array}{c}\text { Moisture, } \\
\%\end{array}$ & $\begin{array}{c}\text { Calorific value, } \\
\mathrm{MJ} / \mathrm{kg}\end{array}$ & $\begin{array}{c}\text { Combustion heat, } \\
\mathrm{MJ} / \mathrm{kg}\end{array}$ \\
\hline Beech wood pellet & 41.50 & 4.77 & 31.73 & 1.90 & 2.10 & 18.00 & 16.06 & 17.58 \\
\hline Pine wood pellet & 40.33 & 4.97 & 34.54 & 1.40 & 1.76 & 17.00 & 14.32 & 15.86 \\
\hline
\end{tabular}

\section{RESULTS}

The results of the conducted test generated parameters of the combustion process and the $\mathrm{NO}_{\mathrm{x}}$ content in the flue gas for individual fuels. The results of the first test stage are presented in Table 2. The obtained flue gas temperature was in the range of $103.40-121.70{ }^{\circ} \mathrm{C}$. The average value of the $\mathrm{NO}_{\mathrm{x}}$ concentration obtained through continuous measurement was 265.86 $\mathrm{mg} / \mathrm{m}^{3}$, while the air-fuel equivalence ratio $(\lambda)$ oscillated within $1.61 \pm 0.30$. The mass distribution of $\mathrm{NO}_{\mathrm{x}}$ emission for the first test stage is presented in Figure 2.
The results of pine pellets combustion in the second stage of the study are shown in Table 3. The obtained flue gas temperature was in the range of 79.00 $92.60{ }^{\circ} \mathrm{C}$. In comparison to the first stage of the study, the average $\mathrm{NO}_{x}$ emission decreased by $30.5 \%$. The obtained air-fuel equivalence ratio $(\lambda)$ revealed a significant increase reaching value $2.54 \pm 0.30$. The mass distribution of $\mathrm{NO}_{\mathrm{x}}$ emission is presented in Figure 3.

The measurement results obtained in the third test stage are presented in Table 4 . The mixed pellets achieved a flue gas temperature of $100.70-117.70^{\circ} \mathrm{C}$, an intermediate between the first and the second stage. The $\mathrm{NO}_{\mathrm{x}}$ concentration was slightly lower than in the case of the first stage of the study and its average value

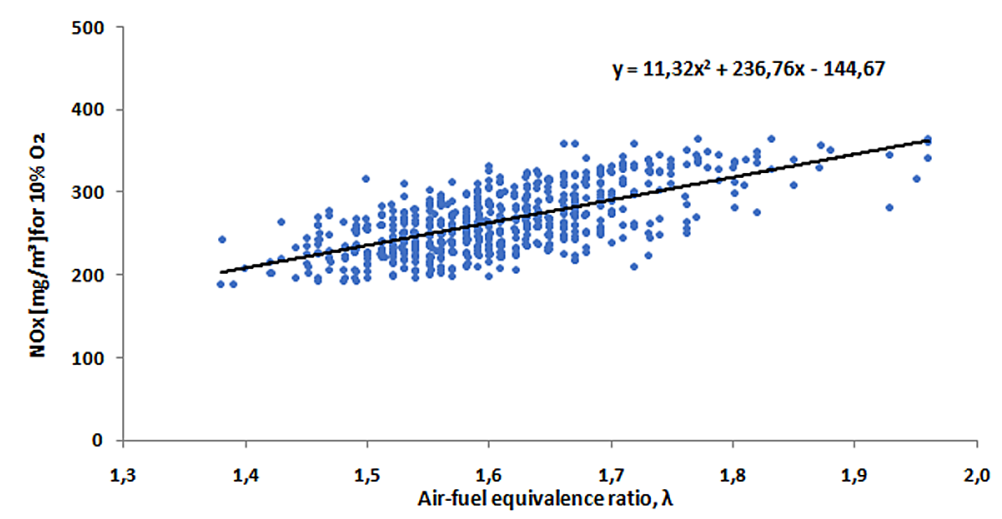

Fig. 2. $\mathrm{NO}_{\mathrm{x}}$ mass distribution in the first test stage

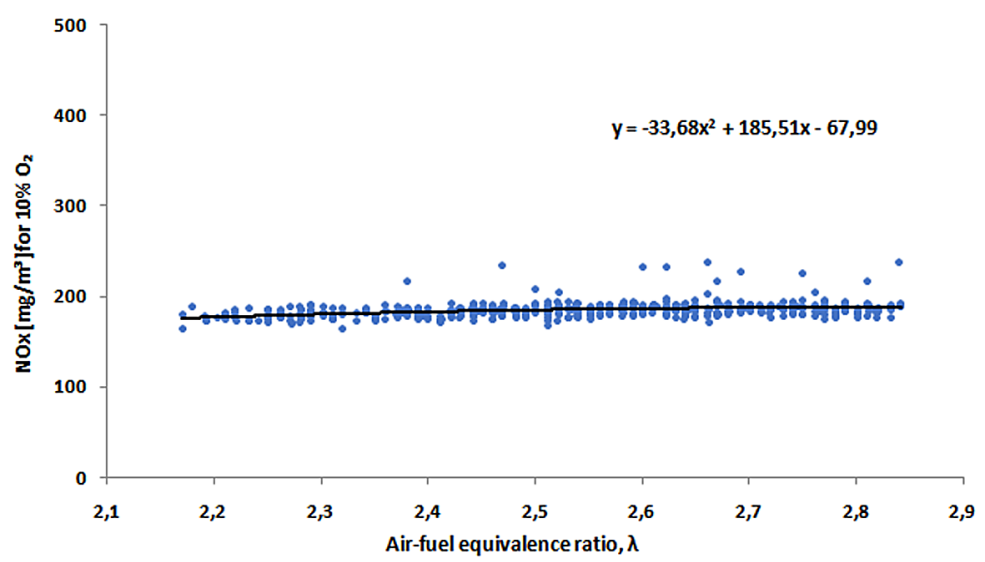

Fig. 3. $\mathrm{NO}_{\mathrm{x}}$ mass distribution in the second test stage

Table 2. Measurement results of the first test stage

\begin{tabular}{|l|c|c|c|c|}
\hline \multicolumn{1}{|c|}{ Value } & $\mathrm{O}_{2}, \%$ & $\mathrm{NO}_{x^{\prime}}, \mathrm{mg} / \mathrm{m}^{3}$ & $\mathrm{~T}_{\mathrm{SP}}{ }^{\circ} \mathrm{C}$ & $\lambda$ \\
\hline Minimum & 5.99 & 189.22 & 103.40 & 1.38 \\
\hline Maximum & 10.36 & 364.38 & 121.70 & 1.96 \\
\hline Average & 7.97 & 265.86 & 114.44 & 1.61 \\
\hline
\end{tabular}

Table 3. Measurement results of the second test stage

\begin{tabular}{|l|c|c|c|c|}
\hline \multicolumn{1}{|c|}{ Value } & $\mathrm{O}_{2}, \%$ & $\mathrm{NO}_{x}, \mathrm{mg} / \mathrm{m}^{3}$ & $\mathrm{~T}_{\mathrm{SP}},{ }^{\circ} \mathrm{C}$ & $\lambda$ \\
\hline Minimum & 11.31 & 164.22 & 79.00 & 2.17 \\
\hline Maximum & 13.60 & 238.59 & 92.60 & 2.84 \\
\hline Average & 12.68 & 184.83 & 82.32 & 2.54 \\
\hline
\end{tabular}




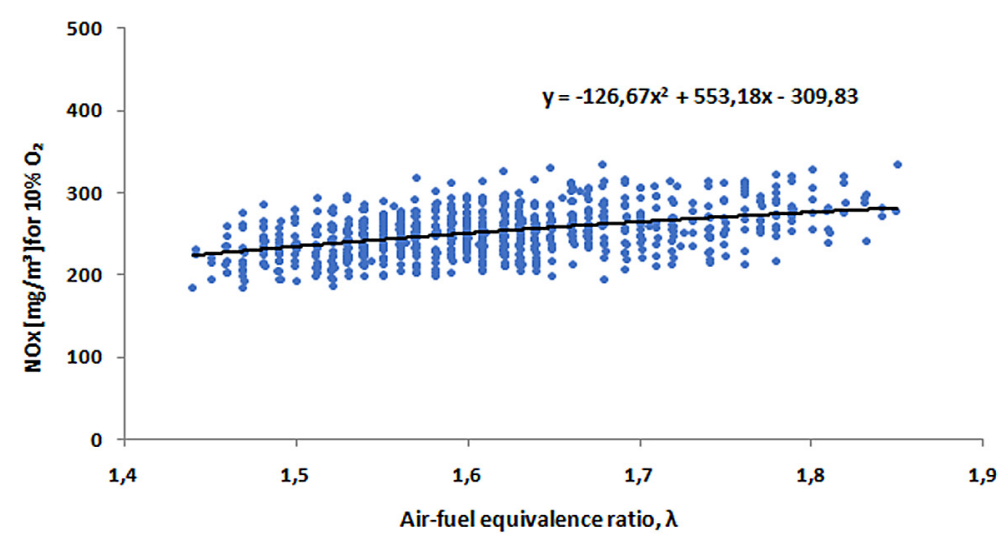

Fig. 4. $\mathrm{NO}_{\mathrm{x}}$ mass distribution in the second test stage

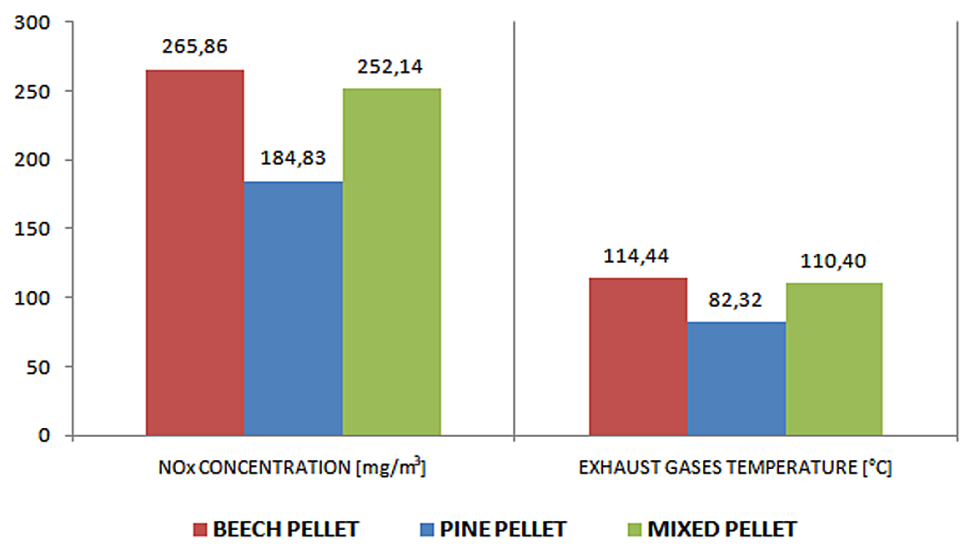

Fig. 5. Exhaust gas temperatures and $\mathrm{NO}_{\mathrm{x}}$ concentrations for three types of pellets

Table 4. Measurement results of the third test stage

\begin{tabular}{|l|c|c|c|c|}
\hline \multicolumn{1}{|c|}{ Value } & $\mathrm{O}_{2}, \%$ & $\mathrm{NO}_{x^{\prime}} \mathrm{mg} / \mathrm{m}^{3}$ & $\mathrm{~T}_{\mathrm{SP}}{ }^{\circ} \mathrm{C}$ & $\lambda$ \\
\hline Minimum & 6.46 & 183.91 & 100.70 & 1.44 \\
\hline Maximum & 9.67 & 333.59 & 117.70 & 1.85 \\
\hline Average & 8.01 & 252.14 & 110.40 & 1.61 \\
\hline
\end{tabular}

was $252.14 \mathrm{mg} / \mathrm{m}^{3}$. The air-fuel equivalence ratio $(\lambda)$ was similar to the first stage and its average value also reached $1.61 \pm 0.20$. The $\mathrm{NO}_{\mathrm{x}}$ mass distribution for the third stage is shown in Figure 4 and the relationship between the flue gas temperature and $\mathrm{NO}_{\mathrm{x}}$ emissions for all test stages is presented in Figure 5.

\section{CONCLUSIONS}

This study investigated the impact of different pellet types on the $\mathrm{NO}_{x}$ emissions during the combustion processes in a low-power heating boiler. The obtained results demonstrate lower $\mathrm{NO}_{\mathrm{x}}$ concentrations in flue gas when using the wood pellets originating from the pine tree waste. The higher content of elemental oxygen in this fuel achieved an increased airfuel equivalence ratio $(\lambda)$ and, the lowest temperature of flue gas among all stages of the study. The flue gas temperature was higher while burning the beech pellets due to a higher calorific value of this fuel and the highest $\mathrm{NO}_{\mathrm{x}}$ content in flue gas. While studying mass distributions, it was observed that the $\mathrm{NO}_{\mathrm{x}}$ concentration increases noticeably along with an increase of the air-fuel equivalence ratio $(\lambda)$. On the other hand, combustion of the mixed fuel shows a mild and small increase of emissions when the air-fuel equivalence ratio $(\lambda)$ increased. Therefore, the presence of pine in fuel has a positive effect on the combustion process, because it reduces the $\mathrm{NO}_{\mathrm{x}}$ formation. From the point of view of thermodynamic parameters and chemistry of combustion processes, the conducted study confirmed the existence of a strong dependency between the changes of the flue gas temperature and the formation of $\mathrm{NO}_{\mathrm{x}}$. The highest flue gas temperature during the beech pellet combustion went hand in hand with the most elevated level of the $\mathrm{NO}_{\mathrm{x}}$ generation. The study is the basis for further research on the reorganization of the combustion process in terms of the $\mathrm{NO}_{\mathrm{x}}$ reduction and it is also a good way to expand the knowledge in this area.

\section{Acknowledgements}

The research was financed by the European Union from the European Regional Development 
Fund through the National Centre for Research and Development (Narodowe Centrum Badań i Rozwoju) - a research project within the Smart Growth Program (contract No. POIR.04.01.04-00-0135/16).

\section{REFERENCES}

1. Boman C., Pettersson E., Westerholm R., Boström D., Nordin A. 2011. Stove Performance and Emission Characteristics in Residential Wood Log and Pellet Combustion, Part 1: Pellet Stoves. Energy Fuels, 25(1), 307-314.

2. Cao Y., Pawłowski A. 2013. Biomass as an answer to sustainable energy. Opportunity versus challenge. Environ. Prot. Eng., 39(1), 153-161.

3. Ciupek B. 2019. Wpływ pary wodnej dostarczanej do procesu spalania węgla kamiennego na skład chemiczny spalin. Przemysł Chemiczny, 98(11), 1768-1772.

4. Ciupek B., Janeba-Bartoszewicz E., Urbaniak R. 2019. Wpływ rozdrobnienia i zwiększonej wilgotności paliw węglowych na skład chemiczny spalin. Przemysł Chemiczny, 98(8), 1283-1285.

5. Ciupek B., Judt W., Urbaniak R., Kłosowiak R. 2019. The Emission of Carbon Monoxide and Nitrogen Oxides from Boilers Supplied by a Pellet under the Influence of Changes in the Air-Fuel Equivalence Ratio. Journal of Ecological Engineering, 20(10), 34-38.

6. El-Sayed S., Khairy M. 2018. An Experimental Study of Combustion and Emissions of Wheat Straw Pellets in High-Temperature Air Flows. Combustion Science and Technology, 190(2), 222-251.

7. Eskilsson D., Rönnbäck M., Samuelsson J., Tullin C. 2004. Optimisation of efficiency and emissions in pellet burners. Biomass and Bioenergy, 27(6), 541-546.

8. Fiedler F., Persson T. 2009. Carbon monoxide emission of combined pellet and solar heating systems. Applied Energy, 86(2), 135-143.

9. Filbakk T., Jirjis R., Nurmi J., Høibø O. 2011. The effect of bark content on quality parameters of Scots pine (Pinus sylvestris L.) pellets. Biomass and Bioenergy, 35(8), 3342-3349.

10. Hardy T., Musialik-Piotrowska A., Ciołek J., Mościcki K., Kordylewski W. 2012. Negative effects of biomass combustion and co-combustion in boilers. Environ. Prot. Eng., 38(1), 25-33.

11. Holubcik M., Jandacka J., Nosek R., Barański J. 2018. Particulate Matter Production of Small Heat Source Depending on the Bark Content in Wood Pellets. Emission Control Science and Technology, 4(1), 33-39.

12. Hroncová E., Ladomerský J., Valíček J., Dzurenda L. 2016. Combustion of Biomass Fuel and Residues: Emissions Production Perspective. Developments in Combustion Technology, 1.

13. Joseph B., Hengsen F., Bühle L., Wachendorf M. 2018. Solid Fuel Production from Semi-Natural Grassland Biomass-Results from a CommercialScale IFBB Plant. Energies, 11(11), 3011.
14. Junga R., Wzorek M., Kaszubska M. 2017. Technical and environmental performance of $10 \mathrm{~kW}$ understocker boiler during combustion of biomass and conventional fuels. E3S Web Conf., 19, 01009.

15. Juszczak M. 2016. Comparison of CO and NOx concentrations from a $20 \mathrm{~kW}$ boiler for periodic and constant wood pellet supply. Environment Protection Engineering, 42(3), 95-107.

16. Khodaei H., Al-Abdeli Y.M., Guzzomi F., Yeoh H.G. 2015. An overview of processes and considerations in the modelling of fixed-bed biomass combustion. Energy, 88, 946-972.

17. Kirsanovs V., Žandeckis A., Veidenbergs I., Blumbergs I., Gedrovičs M., Blumberga D. 2014. Experimental study on optimization of the burning process in a small scale pellet boiler due to air supply improvement. Agronomy Research, 12(2), 499-510.

18. Konieczyński J., Komosiński B., Cieślik E., Konieczny T., Mathews B., Rachwał T., Rzońca G. 2017. Research into properties of dust from domestic central heating boiler fired with coal and solid biofuels. Arch. Environ. Prot., 43(2), 20-27.

19. Mitchell E.J.S., Lea-Langton A.R., Jones J.M., Williams A., Layden P., Johnson R. 2016. The impact of fuel properties on the emissions from the combustion of biomass and other solid fuels in a fixed bed domestic stove. Fuel Process. Technol., 151, 117-125.

20. Morán J.C., Miguez J.L., Granada E., Porteiro J., López-González L.M. 2006. Effect of Different Configurations on Small Pellet Combustion Systems. Energy Sources, Part A(12), 1135-1148.

21. Müllerová J., Hloch S., Valíček J. 2010. Reducing Emissions from the Incineration of Biomass in the Boiler. Chemické listy, 104, 876-879.

22. Musialik-Piotrowska A., Kordylewski W., Ciołek J., Mościcki K. 2010. Characteristics of air pollutants emitted from biomass combustion in small retort boiler. Environ. Prot. Eng., 36(2), 123-131.

23. Piaskowska-Silarska M. 2014. Analiza możliwości pozyskania energii z biomasy w Polsce. Polityka Energetyczna - Energy Policy Journal, 17(4), 239-247.

24. Polák M., Neuberger P. 2008. The Optimisation of Biomass Combustion in Small Boilers. Infrastructure And Ecology of Rural Areas, 6, 63-70.

25. Rabczak S., Proszak-Miąsik D. 2016. Effect of the type of heat sources on carbon dioxide emissions. Journal of Ecological Engineering, 17(5), 186-191.

26. Ratajczak E., Szostak A., Bidzińska G., Herbeć M. 2012. Demand for wood biomass for energy purposes in Poland by 2015. Drewno. (Pr. Nauk. Donies. Komunik.) 55(187), 51-63.

27. Wiinikka H., Gebart R. 2005. The Influence of Fuel Type on Particle Emissions in Combustion of Biomass Pellets. Combustion Science and Technology, 177(4), 741-763.

28. Zhang J., Smith K.R. 2007. Household Air Pollution from Coal and Biomass Fuels in China: Measurements, Health Impacts, and Interventions. Environmental Health Perspectives, 115(6), 848-855. 